This is the final peer-reviewed accepted manuscript of:

Kata Kerekes, Paolo Bonilauri, Andrea Serraino, Federica Giacometti,Silvia Piva, Vittorio Zambrini, Alessandra Canever, Zsuzsa Farkas \& Árpád Ambrus (2016): An effective self-control strategy for the reduction of aflatoxin $M 1$ content in milk and to decrease the exposure of consumers, Food Additives \& Contaminants: Part A, Volume 33, Issue 12, 1 December 2016, Pages 1840-1849.

The final published version is available online at:

http://dx.doi.org/10.1080/19440049.2016.1241895

Rights / License:

The terms and conditions for the reuse of this version of the manuscript are specified in the publishing policy. For all terms of use and more information see the publisher's website.

This item was downloaded from IRIS Università di Bologna (https://cris.unibo.it/)

When citing, please refer to the published version. 


\section{An effective self-control strategy for the reduction of aflatoxin M1 content in milk and to decrease the exposure of consumers}

Kerekes, Kata ${ }^{\mathrm{a},{ }^{*}}$; Bonilauri, Paolo ${ }^{\mathrm{b}}$; Serraino, Andrea ${ }^{\mathrm{c}}$; Giacometti, Federicac ${ }^{\mathrm{c}}$ Piva, Silvia ${ }^{\mathrm{c}}$ Z Zambrini, Vittorio $^{\mathrm{d}}$; Canever, Alessandra ${ }^{\mathrm{d}}$; Farkas, Zsuzsa ${ }^{\mathrm{a}}$; Ambrus, Árpád ${ }^{\mathrm{a}}$

a. Directorate for Food Safety Risk Assessment, National Food-Chain Safety Office; b. Institute for Zooprophylaxis in Lombardy and Emilia-Romagna; c. Department of Veterinary Medical Sciences, Alma Mater Studiorum, University of Bologna; d. Granarolo S.p.A.

Contact of authors:

Kata Kerekes (corresponding author)

Postal address: National Food Chain Safety Office, Directorate for Food Safety Risk Assessment, Kitaibel Pál u. 4., 1024 Budapest, Hungary

Phone: +36202356231

Email: kerekes.kata@gmail.com

\section{Bonilauri Paolo}

Postal address: Institute for Zooprophylaxis in Lombardy and Emilia-Romagna, Via Pitagora 2, 42100 Reggio Emilia, Italy

Phone: +39052 2640613

Email: paolo.bonilauri@izsler.it

\section{Andrea Serraino:}

Postal address: Dept. Scienze Mediche Veterinarie, Universita degli Studi di Bologna, via Tolara di Sopra 50, 40064 Bologna, Italy

Phone: +390512097323

Email: andrea.serraino@unibo.it

\section{Federica Giacometti}

Postal address: Dept. Scienze Mediche Veterinarie, Universita degli Studi di Bologna, via Tolara di Sopra 50, 40064 Bologna, Italy

Phone: +390512097320

Email: federica.giacometti@unibo.it

\section{Silvia Piva}

Postal address: Dept. Scienze Mediche Veterinarie, Universita degli Studi di Bologna, via Tolara di Sopra 50, 40064 Bologna, Italy

Phone: +390512097064

Email: silvia.piva@unibo.it

\section{Angelo Vittorio Zambrini}

Postal address: Granarolo S.p.A., Via Cadriano 27/2 40127 Bologna, Italy

Phone: +390514162311

Email: vittorio.zambrini@granarolo.it

\section{Alessandra Canever}

Postal address: Granarolo S.p.A., Via Cadriano 27/2 40127 Bologna, Italy

Phone: +390514162311

Email: alessandra.canever@granarolo.it

\section{Zsuzsa Farkas}

Postal address: National Food Chain Safety Office, Directorate for Food Safety Risk Assessment, Kitaibel Pál u. 4., 1024 Budapest, Hungary

Phone: +36 307779725

Email: farkas.zsuzsa13@gmail.com

Árpád Ambrus (Retired scientific adviser, previously at National Food-Chain Safety Office, Directorate for Food Safety Risk Assessment)

Postal address: Hómező u. 41., 1221 Budapest, Hungary

Phone: +36 309352432

Email: ambrusadr@yahoo.co.uk

\footnotetext{
"Corresponding author. E-mail: kerekes.kata@ @mail.com; Phone: + 3620235 6231; Postal address: National Food Chain Safety Office, Directorate for Food Safety Risk Assessment, Kitaibel Pál u. 4., 1024 Budapest, Hungary
} 


\section{Abstract}

The study reports on the results of testing the sensitivity of an early warning sampling plan in detecting milk batches with high AFM1 concentration. The effectiveness of the method was investigated by the analysis of 9017 milk samples collected in Italian milk processing plants that applied control plans with different action limits $(\mathrm{AL})$. In the case of milk processing plants, where $30 \mathrm{ng} \mathrm{kg}^{-1} \mathrm{AL}$ has been applied, the $\mathrm{AFM}_{1}$ contamination was significantly lower at or above the $95^{\text {th }}$ percentile of the milk samples compared to plants that used $40 \mathrm{ng} \mathrm{kg}^{-1} \mathrm{AL}$. The results show that the control plan can be used effectively for early warning of occurrence of high $\mathrm{AFM}_{1}$ contamination of milk and to carry out pro-active measures to limit the level of contamination. Estimation of dietary exposure was also carried out, based on the aflatoxin $\mathrm{M}_{1}$ content of the milk samples and on Italian food consumption data. Estimated Daily Intakes (EDI) and Hazard Indices (HI) were calculated for different age groups of the population. HIs show that in case of adult population no adverse effects are expected, but in case of children under age three, the approximate HI values were considerably higher, which underlines the importance of the careful monitoring and control of aflatoxin $\mathrm{M}_{1}$ in milk and dairy products.

Keywords: Aflatoxins; Milk; Statistical analysis; Exposure assessment 


\section{Introduction}

Aflatoxins are produced by Aspergillus flavus, Aspergillus parasiticus and Aspergillus nominus under favourable growing and storage conditions (WHO 1997; Giorni et al. 2007). They may contaminate feed, especially in tropical and subtropical climatic environment, but they have also been detected in maize grown in other areas such as Italy (Prandini et al. 2009) and Spain (Cano-Sancho et al. 2013). According to the 2013 RASFF Annual Report, most of the notifications related to mycotoxins in feed (21 out of 37) concerned maize products, mostly from south-eastern Europe (EC 2014; RASFF 2013 annual report). As an impact of climate change, the infected areas may further increase (EFSA 2012a). Aflatoxin $\mathrm{M}_{1}$ and $\mathrm{M}_{2}$, the metabolites of aflatoxins $\mathrm{B}_{1}$ and $\mathrm{B}_{2}$ can be found in milk of animals fed with feed contaminated with aflatoxins, and $\mathrm{AFM}_{1}$ contamination in milk was reported from several European countries (EFSA 2004; Cano-Sancho et al. 2013; Duarte et al. 2013; Tsakiris et al. 2013; Trevisani et al. 2014). According to Prandini and his co-workers, if contaminated feed has been used, $\mathrm{AFM}_{1}$ appears in the milk after two or three days, and the depuration interval is about the same after the animals are again fed with $\mathrm{AFB}_{1}$-free feed. Once milk becomes contaminated with $\mathrm{AFM}_{1}$ neither pasteurization nor sterilization makes a significant change in the concentration of $\mathrm{AFM}_{1}$ in it. Moreover, since $\mathrm{AFM}_{1}$ associates with the casein fraction of milk, processes like cheese-making carries over $\mathrm{AFM}_{1}$ to the final products (Prandini et al. 2009). Considering these facts and also that there is no procedure at the moment for complete elimination of $\mathrm{AFM}_{1}$ from milk (Ismail et al. 2015), preventing or limiting contamination of milk with aflatoxins should have priority among the reduction strategies.

Milk is a basic food item for all age groups and gender of the human population, especially for children, due to its nutritional value. Milk contains high-quality protein, which includes all essential amino acids and has high antioxidant capacity - especially its casein fraction (Zeluta et al. 2009). Milk contributes significantly to the intake of calcium, magnesium, selenium, riboflavin, vitamin $\mathrm{B}_{12}$ and pantothenic acid. Milk lipids serve as a carrier for fat-soluble vitamins, and the complex fat content of milk contains around 400 types of fatty acids (Weaver et al. 2013). According to EFSA's Comprehensive Food Consumption Database, the mean daily consumption of cow milk is in the range of 42.3 to $292.9 \mathrm{~g} /$ day among adults in Europe. The large portion size represented by the $95^{\text {th }}$ percentile average consumption is $592 \mathrm{~g} /$ day for toddlers and $483 \mathrm{~g} /$ day for the adult population. Aflatoxins are carcinogenic, mutagenic and genotoxic substances. $\mathrm{AFB}_{1}$ becomes activated during the metabolism and its epoxide form binds strongly to the DNA, causing damages in the helix. The metabolites of $\mathrm{AFB}_{1}$ - such as $\mathrm{AFM}_{1}$ - are poorer substrates for epoxidation and therefore, are less toxic (Wild \& Turner 2002). Although the carcinogenicity of $\mathrm{AFM}_{1}$ is considered 10 times lower than that of $\mathrm{AFB}_{1}$. It has been classified as "possibly carcinogenic to humans" by the International Agency for Research on Cancer (WHO and IARC, 1993), therefore their level in milk should be kept as low as reasonably achievable (WHO 1997; EFSA 2007). In order to reach this goal, the European Commission introduced the principle of establishment of early warning system and taking pro-active 
measures for reducing the contamination (Directive 2002/32/EC of the EP and the Council). The maximum level for $\mathrm{AFM}_{1}$ in raw milk, heat-treated milk and milk for the manufacture of milk-based products set by EC No 1881/2006 is $50 \mathrm{ng} \mathrm{kg}^{-1}$. Consequently, the Italian Ministry of Health defined an 'attention limit' of $40 \mathrm{ng} \mathrm{kg}^{-1}$ (Ministero della Salute 2013), which accommodates the uncertainty of analytical results.

Farkas and co-workers elaborated an early warning sampling plan, based on random sampling and analysis of commingled bulk milk collected by the transport tankers typically from 1-6 dairy farms (Farkas et al. 2014). If the $\mathrm{AFM}_{1}$ concentration exceeded the action limits ranging from 16.7 to $40 \mathrm{ng}$ $\mathrm{kg}^{-1}$ - depending on the number of dairy farms -, the milk samples taken from individual farms were consequently analysed and the necessary pro-active actions were recommended to reduce the chance of mixing the contaminated milk with those complying with the legal limit of $50 \mathrm{ng} \mathrm{kg}^{-1}$. The random sampling plan elaborated is applicable only if the number of milk collecting zones remains constant during a given period of time.

The objective of the present study was to develop and test a generally applicable control plan, which can be used effectively for the early warning of occurrence of $\mathrm{AFM}_{1}$ contamination in milk and making timely pro-active measures to limit the level of contamination. Additionally, the study aimed to use the results of the great number of analyses carried out to estimate the level of exposure of different population groups by the consumption of cow milk.

\section{Materials and methods}

\section{$\mathrm{AFM}_{1}$ data collection}

Altogether 9017 milk samples were collected and analysed for $\mathrm{AFM}_{1}$ between April 2013 and May 2014. 3303 samples were taken during the implementation of a self-control plan of a milk processing plant (called Plant A hereunder) located in Southern Italy, which collects about 40 million litres of milk per year. The milk was collected from 85 farms by eight tankers. In addition, 5714 results of $\mathrm{AFM}_{1}$ analyses carried out by four dairy plants (indicated as NP hereunder), in the Northern, Central and Southern regions were also collected and used for assessing the efficiency of the control plan developed within this study. Two types of milk were collected separately in both cases: high quality milk (HQM) and normal quality milk (NQM), which are differentiated by Italian law, on the basis of their content in fat, protein, somatic cell count, and total bacterial count. The collection route, including 1-15 farms for one tanker was optimized depending on the production and accessibility of the farms. At each occasion, the quantity and type (HQM or NQM) of milk loaded from a farm were recorded, and a sample of milk was collected and labelled for later investigations if needed.

\section{Analysis of samples for AFM}

$\mathrm{AFM}_{1}$ concentration was measured using the ELISA Immunoscreen $\mathrm{AFM}_{1}$ kit (Tecnas.r.l., Trieste, Italy), which was validated within the range of 5-100 $\mathrm{ng} \mathrm{kg}^{-1}$ (Rosi et al. 2007). An HPLC method was used for quantitative confirmation of values above $50 \mathrm{ng} \mathrm{kg}^{-1}$ (legal limit) (Dragacci \& Grosso 2001). 


\section{Pro-active measures for reducing AFM contamination of commingled milk}

In order to avoid the contamination of huge milk quantities with aflatoxin $\mathrm{M}_{1}$, dairy plants applied a self-control plan for the monitoring of the $\mathrm{AFM}_{1}$ content of the consignments. Prior to unloading, samples had been taken from the compartments of each truck, in which milks of different qualities were collected. Depending on the detected $\mathrm{AFM}_{1}$ levels, the following actions had been carried out:

i) $\quad \mathrm{AFM}_{1}$ content of a consignment $\leq 30 \mathrm{ng} \mathrm{kg}^{-1}$ : milk was unloaded and processed without further actions.

ii) $\quad \mathrm{AFM}_{1}$ content of a consignment $>30 \mathrm{ng} \mathrm{kg}^{-1}$ but $\leq 40 \mathrm{ng} \mathrm{kg}^{-1}$ : the milk was unloaded and processed, but each of the samples taken at the dairy farms when the truck had been loaded was also analysed separately.

a. If the sample collected at a farm contained $\mathrm{AFM}_{1}$ above $40 \mathrm{ng} \mathrm{kg}^{-1}$ but less than $50 \mathrm{ng}$ $\mathrm{kg}^{-1}$, the veterinarian visited the farm on the same day and corrective action was started by changing the feed ration of the cows;

b. If the sample of a farm contained $\mathrm{AFM}_{1}$ above $50 \mathrm{ng} \mathrm{kg}^{-1}$ (legal limit), the collection of milk from the farm was suspended. Moreover, not only the corrective action had been applied in these cases, but samples were also taken and analysed every three days until the $\mathrm{AFM}_{1}$ concentration declined below $40 \mathrm{ng} \mathrm{kg}^{-1}$.

iii) $\quad \mathrm{AFM}_{1}$ content of a consignment $>40 \mathrm{ng} \mathrm{kg}^{-1}$ but $\leq 50 \mathrm{ng} \mathrm{kg}^{-1}$, the milk was processed, and the respective authority was notified according to the regulation of the Ministry of Health. Corrective actions at farms providing milk with $\mathrm{AFM}_{1}$ content above 40 or $50 \mathrm{ng} \mathrm{kg}^{-1}$ were applied as reported under points ii)a. and ii)b.

iv) $\quad \mathrm{AFM}_{1}$ content of a consignment $>50 \mathrm{ng} \mathrm{kg}^{-1}$ : the same actions took place as reported under point iii). In addition, the milk consignment was discarded.

In case of NP, points iii) and iv) of the above described action plan were applied.

\section{Statistical evaluation of the distribution of AFM concentrations}

The P percentiles of the $\mathrm{AFM}_{1}$ concentrations were calculated by the NIST procedure (NIST/SEMATECH 2003). The rank numbers of their standard deviations were calculated based on normal approximation (Diem \& Seldrup 1982):

$$
s=\sqrt{N \times P \times q}
$$

where $\mathrm{N}$ is the number of $\mathrm{AFM}_{1}$ concentration values in the dataset, $\mathrm{P}$ is the selected percentile and $\mathrm{q}=1-\mathrm{P}$.

The 95\% confidence intervals are calculated as:

$$
R p_{\text {lower }}^{\text {upper }}=\mathrm{R}_{\mathrm{p}} \pm 1.96 \mathrm{~s}
$$

where $R_{p}$ is the rank number of selected percentile. 
The $\mathrm{AFM}_{1}$ concentrations corresponding to the calculated rank numbers of the ordered dataset encompass the $95 \%$ concentration range of the $\mathrm{AFM}_{1}$ concentration corresponding to the $\mathrm{R}_{\mathrm{p}}$. The confidence intervals for the mean $\mathrm{AFM}_{1}$ concentration values were calculated as:

$$
C I_{0.95}=\bar{C}_{A F M 1} \pm 1.96 \times \frac{S D}{\sqrt{N}}
$$

where $\mathrm{SD}$ is the standard deviation of $\mathrm{AFM}_{1}$ concentrations in $\mathrm{N}$ samples and $\bar{C}_{A F M 1}$ is the average concentration. No correction was needed for the calculation of SD due to the large number of concentration values.

\section{Dietary risk assessment and risk characterization}

Food consumption data were obtained from the EFSA Comprehensive European Food Consumption Database. The original data were reported by Italy based on the results of the Italian National Food Consumption Survey (INFCS) conducted from October 2005 to December 2006. It involved 3322 consumers from 1329 households located in the four main geographical areas of Italy (North-West, North-East, Centre and South and Islands) (Leclercq et al. 2009; EFSA Comprehensive Database). The average with standard deviation, median, $95^{\text {th }}$ and $99^{\text {th }}$ percentile consumption data of cow milk were reported for each age class: infants ( $\leq 11$ months); toddlers (from 12 to 35 months); children (36 months to 9 years); adolescents (10-17 years); adults (18-64 years); elderly (65-74 years); very elderly (75 years and older). The consumption data of dairy products and milk based beverages were not included in the exposure assessment.

Left censored data $\left(\mathrm{AFM}_{1}\right.$ concentrations < LOD) were calculated with $0.5 \mathrm{LOD}$ as recommended for cases where the non-quantified results were $<60 \%$ (EFSA 2010).

As $80^{\text {th }}$ percentile milk consumption values were not available, therefore the $80^{\text {th }}$ percentile $\mathrm{AFM}_{1}$ concentration was selected as the basis for worst-case scenario calculation as a conservative estimate of long-term intake. For the EDI calculation, the weighted mean $\mathrm{AFM}_{1}$ concentrations unloaded from each tanker and the average consumption were used. The weighted monthly mean $\mathrm{AFM}_{1}$ values for each month were computed by multiplying the quantities of milk and their $\mathrm{AFM}_{1}$ concentrations (including left censored data) in the sampled tanker and the sum of these values were divided by the sum of total milk quantities of the given month. For the conservative intake estimation, the same method was used, but the weighted $80^{\text {th }}$ percentile $\mathrm{AFM}_{1}$ concentrations were inserted into the equation instead of the weighted means.

The estimated daily intakes (EDI: $\mathrm{ng} \mathrm{kg}^{-1}$ bw day-1) for the population groups were calculated with a deterministic method:

$$
E D I=\frac{\sum C_{A F M_{1}} * A M C}{b w * 365}
$$

where $C_{A F M_{1}}$ is the aflatoxin $\mathrm{M}_{1}$ concentration $\left(\mathrm{ng} \mathrm{kg}^{-1}\right), A M C$ is the average milk consumption ( $\mathrm{kg} /$ year) and $b w$ is the average body weight $(\mathrm{kg})$ of the given population group. 
In view of the facts that aflatoxins are genotoxic and carcinogenic, it is not possible to identify an intake without risk (EFSA, 2004). Kuiper-Goodmann (1990) proposed to derive a safe dose of $0.2 \mathrm{ng}$ $\mathrm{kg}^{-1}$ for $\mathrm{AFM}_{1}$ from the dose causing $50 \%$ of the animals developing tumour $\left(\mathrm{TD}_{50}\right)$ divided by a safety factor of 50000 . The Hazard Index (HI) was calculated by dividing the estimated daily intake with 0.2. The same approach was also used in other studies (Shundo et al. 2009, Duarte et al. 2013; Tsakiris et al. 2013;).

Following the EFSA advice, to carry out risk assessment of substances, which are both genotoxic, and carcinogenic, the Margin of Exposure (MoE) was calculated as follows:

$$
\mathrm{MoE}=\frac{B M D L_{10}}{E D I}
$$

where $\mathrm{BMDL}_{10}$ is the benchmark dose for a $10 \%$ increase in Hepatocellular carcinoma (HCC) incidence compared to the control group. In the case of $\mathrm{AFB}_{1}$ (used as a conservative value) $\mathrm{BMDL}_{10}$ is $870 \mathrm{ng} \mathrm{kg}^{-1}$ bw day ${ }^{-1}$ (EFSA, 2007), which was divided by the mean and $80^{\text {th }}$ percentile EDI values for each age category of consumers. The calculation was carried out for each month from April 2013 to May 2014.

Risk Potency (RP) was calculated assuming that $2 \%$ of the population is $\mathrm{HBV}^{+}$(considering that the prevalence of carriers of hepatitis B (HBV) in the Italian population is between $1.2 \%$ and $2 \%$ ).

Because the carcinogenic potency of aflatoxin is higher in carriers of hepatitis B virus surface antigen than in individuals not being carriers, the potency values suggested by JECFA: 0.3 and 0.01 in $\mathrm{HBV}^{+}$ and $\mathrm{HBV}^{-}$population respectively (JECFA 2001) were used as follows (Cano-Sancho et al. 2013):

$$
R P=(0.01 \times 0.98)+(0.3 \times 0.02)=0.016 \text { HCC per year per } 100,000 \text { person }
$$

Equation (6)

The Risk Potency value was then used to calculate the fraction of incidence of liver cancer (LCI) in the Italian population attributable to the intake of milk contaminated with $\mathrm{AFM}_{1}$ in the following way:

$$
L C I=\frac{R P \times B M D L_{10}}{M o E}=\frac{0.016 \times 870}{\frac{870}{E D I}}=0.016 \times E D I
$$

The fraction of incidence of HCC attributable to intake of $\mathrm{AFM}_{1}$ was calculated on the basis of MoE considering the mean and the $80^{\text {th }}$ percentile of exposure estimation ( $\mathrm{MoE}_{\text {mean }}$ and $\left.\mathrm{MoE}_{\mathrm{P} 0.8}\right)$.

\section{Results and discussion}

Distribution of $A F M_{1}$ concentrations and comparison of milk contaminations in plants $A$ and NP

Distributions of $\mathrm{AFM}_{1}$ concentrations in commingled milk discharged by the tankers are illustrated in Table 1. In Plant A, where the more stringent control plan was applied, even the highest values were below the legal limit, unlike in the case of NP, where some values were twice or three times higher. 
The selected percentile values of $\mathrm{AFM}_{1}$ concentrations with their $95 \%$ confidence limits are given in Table 2. The results show that there was no significant difference between the $\mathrm{AFM}_{1}$ concentration of high and normal quality milks, either in Plant A or in NP. The applied stricter sampling plan in Plant A mainly influenced the frequency of occurrence of high concentration values in the $95^{\text {th }}-99^{\text {th }}$ percentile range.

The number of samples taken from Plant A and from NP is presented in Table 3. The table shows the percentages of samples in each plant that resulted in $30 \mathrm{ng} \mathrm{kg}^{-1} \mathrm{AFM}_{1}$ concentration or above. The measured values are aggregated in the table in order to show the distribution of the high values in both plants. The table shows that in 2013 as well as in 2014 less samples resulted in $\mathrm{AFM}_{1}$ concentration values at or above $30 \mathrm{ng} \mathrm{kg}^{-1}$ in the case of Plant $\mathrm{A}$, where the action limit was set at $30 \mathrm{ng} \mathrm{kg}^{-1}$ compared to NP, which applied the higher $\left(40 \mathrm{ng} \mathrm{kg}^{-1}\right)$ action limit. In the NP 31 milk samples $(0.54 \%)$ resulted in $\mathrm{AFM}_{1}$ concentration values at or above the legal limit (50 $\left.\mathrm{ng} \mathrm{kg}^{-1}\right)$, but in Plant $\mathrm{A}$, none of the samples resulted in $\mathrm{AFM}_{1}$ concentration above $50 \mathrm{ng} \mathrm{kg}^{-1}$ during the examined period. Figure 2 shows the monthly distribution of $\mathrm{AFM}_{1}$ contamination of the milk sampled in plants $\mathrm{A}$ and NP. Figure 1 as well as Tables 2 and 3 demonstrate the advantage of the action plan used by Plant A, where the stricter (30 $\mathrm{ng} \mathrm{kg}^{-1}$ ) action limit was applied compared to $40 \mathrm{ng} \mathrm{kg}^{-1}$ used in NP. Between the $50^{\text {th }}$ and $90^{\text {th }}$ percentile, there was no significant difference between the $\mathrm{AFM}_{1}$ concentrations of milk processed in the different plants. On the contrary, the $\mathrm{AFM}_{1}$ contamination in NP was higher at or above $95^{\text {th }}$ percentile of the milk samples (Table 2). This indicates that the difference observed above the $90^{\text {th }}$ percentile is attributable to the different control plans applied.

As it was demonstrated by Trevisani et al. (2014), the $\mathrm{AFM}_{1}$ contamination in milk has a substantial seasonal variation due to the change of the $\mathrm{AFB}_{1}$ contamination of feed. The action limit of $30 \mathrm{ng} \mathrm{kg}^{-1}$ enables the early detection of the beginning of the increase of the $\mathrm{AFM}_{1}$ contamination of milk. Table 4 gives some examples of the results of the control plans applied in Plant A. The milk collected from various farms by the tanker was sampled at the time of discharge at the processing plants and the samples taken at individual farms were analysed for $\mathrm{AFM}_{1}$, if the discharged commingled milk contained $\mathrm{AFM}_{1}$ above $30 \mathrm{ng} \mathrm{kg}^{-1}$. The example shows that in case the aflatoxin levels of feed are not controlled properly, it is very important to screen the individual batches of milk at farm level. This way it is possible to prevent the contamination of milk with high levels of $\mathrm{AFM}_{1}$, which could otherwise result in the disposal of entire commingled milk causing great economic losses for the producers.

According to one of the latest reviews on this subject (Flores-Flores et al. 2015), studies conducted in Italy and in other countries show the occurrence of $\mathrm{AFM}_{1}$ levels in milk within the same order of magnitude as it was during our study period. Nonetheless the results cannot be directly used as a basis for the evaluation of the control plan, because the aflatoxin concentrations vary within the year and depend on the geographical location and climatic conditions. 
The $\mathrm{AFM}_{1}$ concentration values of milk samples show the effectiveness of the applied self-control plans. The continuous monitoring of consignments makes possible the early detection of elevated $\mathrm{AFM}_{1}$ levels in milk and the localization of farms, where cows are being fed by contaminated feed. The results show that the $30 \mathrm{ng} \mathrm{kg}^{-1}$ action limit applied in the self-control plans is effective in keeping the $\mathrm{AFM}_{1}$ concentration below the legal limit.

\section{Risk characterization and exposure assessment}

Because of the carcinogenic potential of aflatoxins, JECFA (2001) did not specify a numerical tolerable daily intake (TDI) for aflatoxins and concluded that daily exposure, even $<1 \mathrm{ng} \mathrm{kg}^{-1} \mathrm{bw}$, contributed to the risk of liver cancer.

Figure 2 shows the seasonal variation of estimated daily intakes (EDI) for NQM during the study period (from April 2013 till May 2014) in the populations of adults and toddlers. The aflatoxin concentrations of the two different milk qualities were similar, therefore the HQM values are not shown in the figures. Two different EDI values were calculated using equation (4) in the case of both milk qualities. $\mathrm{EDI}_{\text {mean }}$ values were computed by multiplying the weighted mean $\mathrm{AFM}_{1}$ concentration of the given month. The $\mathrm{EDI}_{\mathrm{P} 0.8}$ values were calculated in a similar way but using the $80^{\text {th }}$ percentile of $\mathrm{AFM}_{1}$ concentration instead of the weighted mean. For the adult population, EDI values were calculated with a mean body weight of $70 \mathrm{~kg}$, and mean milk consumption of $0.102 \mathrm{~kg} \mathrm{day}^{-1}$. For infants, a mean body weight of $5 \mathrm{~kg}$ and the mean milk consumption of $0.086 \mathrm{~kg} \mathrm{day}^{-1}$; for toddlers, a mean body weight of $12 \mathrm{~kg}$ and the mean milk consumption of $0.246 \mathrm{~kg}_{\text {day }}{ }^{-1}$ were used (EFSA Comprehensive Database, EFSA 2012b).

Figure 2. clearly shows that the estimated intakes $\left(\mathrm{ng} \mathrm{kg}^{-1} \mathrm{bw} \mathrm{day}-1\right)$ were significantly higher in the case of toddlers.

The seasonal variations of EDI values are in line with the variation of aflatoxin levels in feed reported by other studies (Farkas et al. 2014; Bilandžić et al. 2015).

Figure 3 shows the average EDI values of the different population groups in case of normal quality milk consumption. The lowest values were observed in the group of adults, while the highest values occurred in the groups of infants and toddlers. The intakes of "high consumers" were approximated by the calculation of $\mathrm{EDI}_{\mathrm{P} 0.8}$ values. According to the results, the estimated daily intake of large portion size consumers is about $40-50 \%$ higher than the average consumers.

The Hazard Indices (HI) were calculated by dividing the estimated daily intake values with 0.2 . In the case of adult and elderly population (Figures 4 and 5), the HIs were less than 0.5 , which means a level at which no adverse effects are expected. The average HI values of all age groups were below one, except for infants and toddlers, where the HIs were between 1 and 2.5 in most months of the studied period indicating that the youngest population groups might be exposed to $\mathrm{AFM}_{1}$ above the safe level. It is important to note that according to the Italian food consumption survey, only $25 \%$ of the infant population is being fed with cow milk, but among toddlers, the ratio of cow milk consumers is $91.7 \%$. 
Taking into account that the daily consumption values included not all kinds of milk and dairy products, only cow milk, the overall $\mathrm{HI}$ values of $\mathrm{AFM}_{1}$ for this food category might be even higher. The liver cancer incidence attributable to $\mathrm{AFM}_{1}$ was calculated using the cancer potency of 0.016 hepatocellular carcinoma/year/100,000 persons. In the study period, the incidence estimated with the mean $\mathrm{MoE}$ for the adult population ranged between 0.0001 and 0.0006 cancer cases/year/100,000 persons in the case of HQM and from 0.0002 to 0.0007 cancer cases/year/100,000 persons for NQM. The hepatocellular carcinoma (HCC) incidence estimated with the mean MoE for the population of toddlers ranged between 0.0018 and 0.0067 cancer cases/year/100,000 persons calculated with the HQM results and from 0.0018 to 0.0079 in the case of NQM.

The cancer incidence estimated with the $80^{\text {th }}$ percentile $\mathrm{MoE}$ for the adult population ranged between 0.0001 and 0.0006 cancer cases/year/100,000 persons in the case of HQM and from 0.0001 to 0.0007 cancer cases/year/100,000 persons in the case of NQM. The HCC incidence estimated with the $80^{\text {th }}$ percentile MoE for the population of toddlers ranged between 0.0008 and 0.0089 cancer cases/year/100,000 persons in the case of HQM and from 0.0008 to 0.0105 cancer cases/year/100,000 persons in the case of NQM. The average liver cancer incidence (LCI) values with standard deviations are indicated in Figure 6 for each population groups. The average LCI values are the highest in the groups of infants and toddlers.

According to our results, the most exposed Italian population groups are the infants ( $\leq 11$ months) and toddlers (from 12 to 35 months), but especially toddlers, because, while only $25 \%$ of the infants consume cow milk, this ratio among toddlers is over $90 \%$.

In order to reduce the exposure of children, especially of the ones less than 3 years old, the most sensitive population group - specifically selected milk batches should be used for producing milk and milk products for young children. For each population group, an average EDI less than $0.2 \mathrm{ng} \mathrm{kg}^{-1} \mathrm{bw}$ day $^{-1}$ is necessary to reach in order to get a HI below 1 , a level at which no adverse effects are expected. Considering the average body weights and consumption levels in the Italian population groups, the $\mathrm{AFM}_{1}$ concentration below $11.7 \mathrm{ng} \mathrm{kg}^{-1}$ for infants and a concentration below $9.7 \mathrm{ng} \mathrm{kg}^{-1}$ in the case of toddlers would result an EDI less than $0.2 \mathrm{ng} \mathrm{kg}^{-1}$ bw day ${ }^{-1}$ and consequently a HI below 1. Therefore, milk containing $\mathrm{AFM}_{1} \leq 10 \mathrm{ng} \mathrm{kg}^{-1}$ should be used for producing milk and milk-based products specifically for young children. Considering the uncertainty of analytical measurements $(\sim 18 \%)$, it means that those commingled milk batches discharged from the tankers which contain $\leq 8$ $\mathrm{ng} \mathrm{kg}^{-1} \mathrm{AFM}_{1}$ should be stored and processed separately for the youngest population groups.

The results underline the importance of regular control of produced milk, applying appropriate action limit in combination with immediate corrective actions at farm level. Our study has shown that the applied monitoring plan is sensitive enough to reveal milk batches with high $\mathrm{AFM}_{1}$ concentration and keep the $\mathrm{AFM}_{1}$ concentration below $50 \mathrm{ng} \mathrm{kg}^{-1}$ in commingled milk for general use and selection of batches with low $\left(\leq 8 \mathrm{n} \mathrm{kg}^{-1}\right)$ AFM1 contamination for preparing milk and milk products for infants and toddlers. 


\section{Abbreviations used}

$\mathrm{AFB}_{1} \quad$ Aflatoxin $\mathrm{B}_{1}$

$\mathrm{AFM}_{1} \quad$ Aflatoxin $\mathrm{M}_{1}$

AMC Average milk consumption

BMDL $_{10}$ Benchmark dose lower confidence limit for a 10\% response

BW Body weight

CL Confidence level

$\mathrm{CI}_{0.95} \quad 95 \%$ confidence intervals

EDI Estimated Daily Intake

EFSA European Food Safety Authority

ELISA Enzyme-linked immunosorbent assay

FAO Food and Agriculture Organization of the United Nations

HBV Hepatitis B virus

HCC Hepatocellular carcinoma

HI Hazard Index

HPLC High Performance Liquid Chromatography

HQM High quality milk

IARC International Agency for Research on Cancer

INFCS Italian National Food Consumption Survey

JECFA Joint FAO/WHO Expert Committee on Food Additives

LCI Liver cancer incidence

LCL Lower confidence limit

LOD Limit of detection

MoE Margin of Exposure

$\mathrm{MoE}_{\text {mean }} \quad$ Margin of Exposure considering the mean of exposure estimation

$\mathrm{MoE}_{\mathrm{P} 0.8} \quad$ Margin of Exposure considering the $80^{\text {th }}$ percentile of exposure estimation

NIST National Institute of Standards and Technology

NP Dairy plants in the Northern, Central and Southern regions of Italy

NQM Normal quality milk

SD Standard deviation

$\mathrm{TD}_{50} \quad$ Dose causing $50 \%$ of the animals developing tumour

TDI Tolerable daily intake

UCL Upper confidence limit

WHO World Health Organization 


\section{References}

Bilandžić N, Varenina I, Kolanović BS, Božić Đ, Đokić M, Sedak M, Tanković S, Potočnjak D \&Cvetnić Ž. 2015. Monitoring of aflatoxin M1 in raw milk during four seasons in Croatia. Food Control. doi: 10.1016/j.foodcont.2015.02.015.

Cano-Sancho G, Sanchis V, Marín S, Ramos AJ. 2013. Occurrence and exposure assessment of aflatoxins in Catalonia (Spain). Food Chem. Toxicol. 51:188-193.

Diem K, Seldrup J. 1982. Lenter C. Statistical Tables Mathematical Formulae: Introduction to statistics. Ciba-Geigy Basel (Switzerland); p. 219.

Directive 2002/32/EC of the European Parliament and of the Council of 7 May 2002 on undesirable substances in animal feed, Official Journal of the European Union. L140, 30:10-21.

Dragacci S, Grosso F. 2001. Immunoaffinity Column Cleanup with Liquid Chromatography for Determination of Aflatoxin M1 in Liquid Milk: Collaborative Study. J. AOAC Int. 84:437-443.

Duarte SC, Almeida AM, Teixeria AS, Pereira AL, Falcão AC, Pena A, Lino CM. 2013. Aflatoxin M1 in marketed milk in Portugal: Assessment of human and animal exposure. Food Control. 30:411-417.

European Commission. 2014. Rapid Alert System for Food and Feed (RASFF) annual report 2013. EU Commission - Working Document. p.19. ISBN 978-92-79-38196-6 (PDF). doi:10.2772/33031 (PDF).

European Food Safety Authority. 2004. Opinion of the Scientific Panel on Contaminants in the Food Chain on a request from the Commission related to Aflatoxin B1 as undesirable substance in animal feed. EFSA Journal. 39:1-27. Available from: http://www.efsa.europa.eu/en/efsajournal/pub/39 (accessed Mar 26, 2016)

European Food Safety Authority. 2007. Opinion of the scientific panel on contaminants in the Food Chain on a request from the commission related to the potential increase of consumer health risk by a possible increase of the existing maximum levels for aflatoxins in almonds, hazelnuts and pistachios and derived products. EFSA Journal. 446: 1-127.

European Food Safety Authority. 2010. Management of left-censored data in dietary exposure assessment of chemical substances. EFSA Journal. 8:1557-1853.

European Food Safety Authority 2012a. Scientific report submitted to EFSA: Modelling, predicting and mapping the emergence of aflatoxins in cereals in the EU due to climate change. Question No 
EFSA-Q-2009-00812. Available from: http://www.efsa.europa.eu/en/supporting/doc/223e.pdf (accessed Mar 26, 2016)

European Food Safety Authority 2012b. Scientific Committee; Guidance on selected default values to be used by the EFSA Scientific Committee, Scientific Panels and Units in the absence of actual measured data. EFSA Journal. 10:2579. [32 pp.] doi:10.2903/j.efsa.2012.2579.

European Food Safety Authority Comprehensive European Food Consumption Database [date unknown] [Internet]. Available from: http://www.efsa.europa.eu/en/foodconsumption/comprehensive-database (accessed Mar 26, 2016)

Farkas Zs, Trevisani M, Horváth Zs, Serraino A, Szabó IJ, Kerekes K, Szeitzné Szabó M, Ambrus Á. 2014. Analysis of industry generated data Part II. Risk based sampling plan for efficient self-control of aflatoxin M1 contamination in raw milk. Food Addit. Contam. A. 31:1257-1273.

Flores-Flores ME, Lizarraga E, Lopez de Cerain A, Gonzalez-Penas E. 2015. Presence of mycotoxins in animal milk: A review. Food Control. 53:163-176.

Giorni P, Magan N, Pietri A, Bertuzzi T, Battilani P. 2007. Studies on Aspergillus flavi isolated from maize in northern Italy. Int. J. Food Microbiol. 113:330-338.

Ismail A, Akhtar S, Levin ER, Ismail T, Riaz M, Amir M. 2015. Aflatoxin M1: Prevalence and decontamination strategies in milk and milk products. Crit. Rev. Microbiol. 8:1-10.

Joint FAO/WHO Expert Committee on Food Additives (JECFA). 2001. Safety evaluation of certain mycotoxins in food, WHO/FAO, Geneva, Food Additive Series No. 47.

Kuiper-Goodmann T. 1990. Uncertainties in the risk assessment of three mycotoxins: aflatoxin, ochratoxin, and zearalenone. Can. J. Physiol. Pharm. 68:1017-1024.

Leclercq C, Arcella D, Piccinelli R, Sette S, Le Donne C, Turrini A. 2009. The Italian National Food Consumption Survey INRAN-SCAI 2005-06: main results in terms of food consumption, Public Health Nutr. 12:2504 -2532

Ministero della Salute. 2013. Nota del Ministero della Salute prot. n. 855 del 16/1/2013. Procedure operative straordinarie per la prevenzione e la gestione del rischio contaminazione da aflatossine nella filiera lattiero-casearia e nella produzione del mais destinato all' alimentazione umana e animale, a seguito di condizioni climatiche estreme. [Extraordinary operating procedures for the prevention and management of the contamination risk by aflatoxins in the dairy supply chain and in maize production intended for 'human and animal nutrition, as a result of extreme weather conditions.] 
National Institute of Standards and Technology. [date unknown] E-Handbook of Statistical Methods. [Internet] Available from: http://www.itl.nist.gov/div898/handbook (accessed Jan 17, 2016)

Prandini A, Tansini G, Sigolo S, Filippi L, Laporta M, Piva G. 2009. On the occurrence of aflatoxin M1 in milk and dairy products. Food Chem. Toxicol. 47:984-991.

Rosi P, Borsari A, Lasi G, Lodi S, Galanti A, Fava A, Girotti S, Ferri E. 2007. Aflatoxin M1 in milk: Reliability of the immunoenzymatic assay. Int. Dairy J. 17:429-435.

Shundo L, Navas SA, Conceiçăo L, Lamardo A, Ruvieri V, Sabino M. 2009. Estimate of aflatoxin M1 exposure in milk and occurrence in Brazil. Food Control. 20:655-657.

Trevisani M, Farkas Zs, Serraino A, Zambrini VA, Pizzomiglio V, Giacometti F, Ambrus Á. 2014. Analysis of industry generated data Part I. A baseline for the development of a tool to assist milk industry in the design of sampling plans for controlling aflatoxin $\mathrm{M}_{1}$ in milk Part I. Food Addit. Contam. A. 31:1246-1256.

Tsakiris IN, Tzatzarakis MN, Athanasios K, Alegakis AK, Vlachou MI, Renieri EA, Aristidis M, Tsatsakis AM. 2013. Risk assessment scenarios of children's exposure to aflatoxin M1 residues in different milk types from the Greek market. Food Chem. Toxicol. 56:261-265.

Weaver C, Wijesinha-Bettoni R, McMahon D, Spence L. 2013. Milk and Dairy Products in Human Nutrition. Muehlhoff E, Bennett A, McMahon D. Chapter 4, Milk and dairy products as part of the diet. p. 106-111. Food and Agriculture Organization of the United Nations (FAO): Rome, Italy, EISBN: 978-92-5-107864-8

Wild CP, Turner PC. 2002. The toxicology of aflatoxins as a basis for public health decisions. Mutagenesis. 17:471-481.

World Health Organization. 2012. [date unknown] [Internet]Template for the calculation of the IESTI. Available from: http://www.who.int/entity/foodsafety/chem/IESTI calculation_13c.xlt (accessed Mar 26, 2016)

World Health Organization. 1997. Evaluation of Certain Food Additives and Contaminants, Fortyninth report of the Joint FAO/WHO Expert Committee on Food Additives, WHO Tech. Rep. Ser. 884:69-77.

World Health Organization, International Agency for Research on Cancer. 1993. [Internet] Monographs on the Evaluation of Carcinogenic Risks to Humans, Some Naturally Occurring Substances: Food Items and Constituents, Heterocyclic Aromatic Amines and Mycotoxins, vol. 56. 
Available from: http://monographs.iarc.fr/ENG/Monographs/vol56/mono56-14.pdf (accessed Aug 18, 2016)

Zeluta A, Maurizi A, Frigola A, Esteve MJ, Coli R, Burini G. 2009. Antioxidant capacity of cow milk, whey and deproteinized milk. Int. Dairy J. 19:380-385. 


\section{Figure Captions}

Figure 1: $\mathrm{AFM}_{1}$ contamination $\left[\mathrm{ng} \mathrm{kg}^{-1}\right]$ found in milk samples from the collection tankers in Plants $\mathrm{NP}$ and $\mathrm{A}$ in a monthly distribution. Note: $\mathrm{AFM}_{1}$ concentration values below $30 \mathrm{ng} \mathrm{kg}^{-1}$ and ranging from 60 to $150 \mathrm{ng} \mathrm{kg}^{-1}$ are not shown in the figure.

Figure 2: Monthly variation of the mean and $80^{\text {th }}$ percentile Estimated Daily Intake (EDI) values of the adult population (Adults) and the children between 1 and 3 years of age (Toddlers) from normal quality milk (NQM). Note: the months are indicated with their first character e.g. A13 corresponds to April 2013.

Figure 3: Average Estimated Daily Intake of $\mathrm{AFM}_{1}$ attributable to normal quality milk (NQM) consumption in the different population groups of Italy.

Figure 4: Monthly variation of the Hazard Indices (HI) in case of consumption of normal quality milk (NQM) calculated from the $\mathrm{AFM}_{1}$ contamination measured in Plant $\mathrm{A}$ and the mean and $80^{\text {th }}$ percentile consumption of the adult population and the group of toddlers.

Figure 5: Average Hazard Index values attributable to $\mathrm{AFM}_{1}$ contamination normal quality milk (NQM) consumption in the different population groups of Italy.

Figure 6: Comparison of the average estimated liver cancer incidences (LCI) in the different population groups of Italy attributable to $\mathrm{AFM}_{1}$ in case of average and high contamination of normal quality milk. 
Word count: 6643

Note: The authors declare no competing financial interest. 